\title{
Emocje, afekty, archiwa i selekcja. Ekscytujące drogi nowej humanistyki
}

\author{
Magdalena Wiśniewska-Drewniak \\ Uniwersytet Mikołaja Kopernika w Toruniu / Nicolaus Copernicus University in Toruń (Poland) \\ magwis@umk.pl, ORCID 0000-0001-9119-1372
}

\begin{abstract}
STRESZCZENIE
Artykuł jest próbą wprowadzenia do polskiego obiegu naukowego i spopularyzowania teorii i założeń prezentowanych do tej pory głównie w literaturze anglosaskiej, a dotyczących tematu afektywności (czy też emocjonalnego aspektu) archiwów. W wyniku jakościowej analizy dotychczasowych badań oraz tekstów teoretycznych wskazano cztery obszary tematyczne, oferujące szczególnie ciekawe perspektywy dla badaczy i archiwistów: afekt i selekcja archiwalna; afekt i wykorzystanie archiwów; afekt i opis archiwalny; archiwa i trauma. Szczególnie wiele miejsca poświęcono wartościowaniu dokumentacji i pozycjonowaniu archiwisty w tym procesie. Podjęto również próbę odniesienia tego typu badań do koncepcji nowej humanistyki.
\end{abstract}

SŁOWA KLUCZOWE

emocje, afekt, archiwistyka, selekcja archiwalna, archiwa społeczne, postmodernizm

\section{Emotion, affect, archives and selection. The exciting paths of the new humanities}

\begin{abstract}
This article attempts to introduce and popularize in Polish academia the theories and assumptions, which have so far been presented mainly in the Anglo-Saxon literature on the subject, of the affectivity (or emotional aspect) of archives. Through a qualitative analysis of existing research and theoretical texts, four thematic areas were identified that offer particularly interesting perspectives for researchers and archivists: affect and archival selection; affect and archival use; affect and archival description; and archives and trauma. Particular attention has been given to appraising documentation and positioning the archivist in this process. An attempt is also made to relate this type of research to the concept of new humanities.
\end{abstract}

\author{
KEYWORDS \\ emotions, \\ affect, archival \\ science, appraisal, \\ community archives, \\ postmodernism
}

Jednym $\mathrm{z}$ bardziej interesujących trendów w anglosaskiej archiwistyce ostatnich kilku lat jest spoglądanie na archiwa i dokumentację (w szerokim jej rozumieniu) przez perspektywę afektywności. Celem niniejszego artykułu jest zapoznanie czytelnika z założeniami zwrotu afektywnego oraz stosowania perspektywy afektu w archiwach, a także omówienie kilku najciekawszych w tej materii badań 
odnoszących się do zakresu przedmiotowego archiwistyki (choć czasem omawiane teksty nieco poza ten zakres wychodzą). Artykuł szczególnie dużo miejsca poświęca perspektywie selekcji archiwalnej oraz zaproponowanemu przez Marikę Cifor i Michelle Caswell postulatowi, aby włączyć do tego procesu afektywność jako teoretycznie umocowane kryterium nadawania wartości dokumentacji. Ogromny potencjał badawczy (i do pewnego stopnia również praktyczny) starano się przybliżyć w odniesieniu do lokalnej specyfiki archiwów w Polsce, szczególnie dużo miejsca poświęcając trzem ich typom: archiwom społecznym, prywatnym i państwowym. W efekcie zastosowania metody jakościowej analizy tekstów (gł. literatury anglosaskiej) w kontekście polskiej dziedziny archiwalnej, wskazano na cztery główne obszary tematyczne oferujące szczególnie ciekawe perspektywy dla badaczy i archiwistów: afekt i selekcja archiwalna; afekt i wykorzystanie archiwów; afekt i opis archiwalny; archiwa i trauma. Na zakończenie podjęto próbę pozycjonowania potencjalnych badań z obszaru archiwistyki i afektu w ramach proponowanego przez Ryszarda Nycza konceptu nowej humanistyki.

Pisanie o afektach/emocjach (o tym rozróżnieniu później) napotyka na samym początku na sporą terminologiczną trudność. Mimo prawie trzech dekad, które upłynęły od kiedy emocje stały się popularnym tematem badań w anglosaskich kręgach nauk społecznych i humanistycznych, teoretycy wciąż nie wystosowali jednego, spójnego aparatu pojęciowego. Nie jest to niczym dziwnym, biorąc pod uwagę charakter tego obszaru badawczego, zwłaszcza jego rozległość, a także brak konsensusu co do statusu emocji w organizmie (rozumianym zarówno biologicznie, jak i społecznie). Największą chyba przeszkodą jest jednak wielość metod i podejść teoretycznych do tego zagadnienia związana z faktem, że tematyka emocji stała się przedmiotem badań w tak różnorodnych dyscyplinach i dziedzinach nauki jak np. psychologia i psychiatria, biologia i neurobiologia, (neuro) kognitywistyka, pedagogika, politologia, filozofia, etnologia, kulturoznawstwo i literaturoznawstwo czy historia (a także archiwistyka, o czym traktuje niniejszy artykuł $^{1}$.

$1 \quad$ M.P. Markowski, Emocje. Hasło encyklopedyczne w trzech częściach i dwudziestu trzech rozdziałach (nie liczqc motta), [w:] Pamięć i afekty, red. Z. Budrewicz, R. Sendyka, R. Nycz, Warszawa 2014, s. 347; M. Horodecka, Afekty i emocje w reportażu literackim. Perspektywa genologiczna $i$ antropologiczna, [w:] Kultura afektu - afekty w kulturze. Humanistyka po zwrocie afektywnym, red. R. Nycz, A. Łebkowska, A. Dauksza, Warszawa 2015, s. 416; s. 415-441; P. Tincineto Clough, Introduction, [w:] The Affective Turn: Theorizing the Social, red. P. Ticineto Clough, J. Halley, Durham 2007, s. 1-33; M. Cifor, Affecting relations: introducing affect theory to archival discourse, „Archival Science“ 2016, t. 16, z. 1, s. 10. 
W tym miejscu niemożliwe jest jednak przeprowadzenie czytelnika szczegółowo przez rozwlekłe czasowo i bardzo różnorodne dyscyplinarnie próby definiowania emocji i afektów jako obiektów badań naukowych oraz „obiektów w świecie”. Dla celów artykułu przytoczono tylko niektóre definicje, przedstawiono też relację terminów emocje/afekty - aby łatwiej odnaleźć się w dość skomplikowanym świecie badania archiwów w perspektywie afektywnej.

„Emocje” pochodzą od łacińskiego emovere - poruszać się (stąd też polski, dość archaiczny już, synonim - wzruszenia). W podstawowym ujęciu są to „cielesno-psychiczne reakcje organizmu na bodźce zewnętrzne, prowadzące do zmiany w dotychczasowym zachowaniu"2. W literaturze wymienia się często sześć tzw. emocji podstawowych: gniew, radość, smutek, zdziwienie, lęk i wstręt. Uzupełnione są one o szeroki katalog emocji bardziej złożonych, jak np. wstyd, litość, poczucie winy, żal ${ }^{3}$.

Należy wprowadzić w tym miejscu również pojęcie „afektu” - centralne dla prezentowanego dyskursu, i choć różnorodnie rozumiane, to kluczowe dla zrozumienia języka zwrotu afektywnego (a także dla ewentualnych poszukiwań literatury przedmiotu). Słowo „afekt” pochodzi od łacińskiego czasownika afficere - wywoływać zmiany, wpływać (do czego odnosi się np. współczesna angielszczyzna, gdzie omawiany tutaj termin affect zapisywany jest tak samo jak m.in. czasownik oznaczający wpływanie na coś/kogoś i powodowanie w czymś/ kimś zmiany) ${ }^{4}$.

Pierwszą popularną drogą jest wąskie, somatyczne definiowanie afektu, szczególnie rozpowszechnione przez Briana Massumiego. W tym rozumieniu afekt widzi się jako instynktowną odpowiedź, „bio-fizyko-chemiczną przedświadomą reakcję organizmu na bodziec" ${ }^{5}$. Afekt w takim rozumieniu ma charakter intensywny i nieświadomy, nie podlega kontroli podmiotu, jest stanem zawieszenia umocowanym w ciele. Afekt ma somatyczne źródło, jak również somatyczny sposób ujawniania się ${ }^{6}$. Alina Kolańczyk definiuje afekt jako „chwi-

\footnotetext{
2 M.P. Markowski, op.cit., s. 345.

3 Ibidem, s. 347-349.

4 Affect, [w:] Merriam-Webster.com Dictionary, https://www.merriam-webster.com/dictionary/ affect [dostęp: 29.07.2021].

5 J. Żylińska, Czy mamy bać się końca świata? Afekt, geologia i posthumanizm jako wyznaczniki nowego horyzontu w humanistyce, tłum. P. Poniatowska, [w:] Kultura afektu..., s. 51

6 M. Horodecka, op.cit., s. 416.
} 
lową, pozytywną lub negatywną reakcję organizmu (wegetatywną, mięśniową, doznaniową) na jakąś zmianę w otoczeniu lub w samym podmiocie"7.

Efektem stosowania tak wąskiego rozumienia afektu, właściwie jako wyłącznie reakcji biologicznej, cielesnej, jest rozróżnienie między emocją a afektem. Czynnikiem odróżniającym te fenomeny jest świadomość podmiotu, a więc rzekoma refleksyjność w przypadku emocji i bezrefleksyjność (automatyzm) w przypadku afektu. Afekt może być więc podłożem emocji, jednak nie przekłada się na nie w sposób bezpośredni. Wielu znawców jednak $\mathrm{z}$ takim podejściem się nie zgadza. Badania wskazują bowiem, że również emocje mogą przebiegać nieświadomie, co uniemożliwia stosowanie świadomości podmiotu jako logicznej dystynkcji. Warto zadać sobie również pytanie o praktyczną (w sferze badawczej) stronę odróżniania afektu od emocji, szczególnie w przypadku nauk niekoniecznie zawiadujących aparatem metodologicznym, pozwalającym badać tak skomplikowane zagadnienia jak fizyczne odpowiedzi ciała w przypadku reakcji na bodźce (mowa tu więc w szczególności o naukach społecznych i humanistycznych) $)^{8}$.

Drugie podejście zakłada więc dużo bardziej liberalne traktowanie pojęcia afektu i emocji. Wielu współczesnych badaczy stosuje je zamiennie, jako synonimy, odnosząc się $\mathrm{w}$ ten sposób do uogólnionej sfery emocjonalnej człowieka. Taką strategię przyjęła również M. Cifor, pisząc o wprowadzeniu teorii afektywnej do dyskursu archiwistycznego: „Posługuję się tutaj afektem jako kategorią konstruowaną kulturowo, społecznie i historycznie, która zarówno obejmuje, jak i wykracza poza uczucia i emocje"9. Tak rozumiane emocje/afekty „należą do obfitego continuum, rozciągającego się od bezpośredniej, fizjologicznej, automatycznej reakcji na bodźce do bardziej złożonych, świadomych i refleksyjnych stanów lub postaw wobec świata"10. Niektórzy badacze używają takich sformułowań jak kondycja afektywna (w której skład wchodzą „,wszystkie niewolicjonalne i nieintelektualne reakcje na to, co wydarza się w świecie: emocje, odczucia, uczucia, nastroje, namiętności, pragnienia") ${ }^{11}$ lub stany afektywne (odczucia - sen-

7 A. Kolańczyk, Procesy afektywne i orientacja w otoczeniu, [w:] eadem, A. Fila-Janowska, M. Pawłowska-Fusiara, R. Sterczyński, Serce $w$ rozumie. Afektywne podstawy orientacji $w$ otoczeniu, Gdańsk 2004, s. 16 [za:] M. Horodecka, op.cit., s. 417

8 M. Horodecka, op.cit., s. 418-419.

$9 \quad$ M. Cifor, Affecting relations..., s. 10.

10 M.P. Markowski, op.cit., s. 350.

11 Ibidem. 
sations, uczucia - feelings, nastroje - moods, emocje - emotions, namiętności - passions $)^{12}$. W podobny sposób będę rozumieć również przedmiot niniejszego artykułu, w którym terminy „afekty” i „emocje” są stosowane zamiennie.

Krótko należy jeszcze w tym miejscu odnieść się do terminu „zwrot afektywny”, który jest w użyciu od połowy lat 90. ubiegłego wieku. Według M. Cifor zwrot afektywny polega na tym, że: „badanie afektu stało się przedmiotem zainteresowania naukowców z nauk humanistycznych i społecznych. Ten zwrot reprezentuje coś więcej, niż tylko uczynienie afektów, emocji i uczuć usankcjonowanymi przedmiotami badań naukowych. Poprzez uzasadnione i rygorystyczne przedstawienie i kontemplację tego, co osobiste i subiektywne, wyznacza nowy sposób uprawiania krytyki kultury"13.

Niektórzy badacze z pewną dozą sceptycyzmu podchodzą jednak do terminu „zwrot afektywny”, szczególnie że humanistyka w ostatnich dekadach obwieszczała już kilka zwrotów (m.in. językowy ${ }^{14}$, kulturowy ${ }^{15}$, przestrzenny ${ }^{16}$, neomaterialistyczny $\left.{ }^{17}\right)^{18}$. Bez względu na opinię na temat tego, czy zainteresowanie emocjami należy nazywać kolejnym zwrotem w humanistyce, czy nie, jest to termin często używany i przydatny w poszukiwaniach literatury. Początek zwrotu datuje się najczęściej na 1995 r., kiedy to opublikowano dwa kluczowe dla teorii afektywnej teksty: The Autonomy of Affect (Autonomia afektu) B. Massumiego ${ }^{19}$ oraz Shame in the Cybernetic World (Wstyd w cybernetycznym świecie) Evy Kosofsky Sedgwick i Adama Franka ${ }^{20}$.

Nie ulega jednak wątpliwości, że emocje były tematem rozważań akademików, a w szczególności filozofów, od dużo dłuższego czasu. Niemal cała zachodnia re-

12 C. Altieri, The Particulars of Rapture: An Aesthetics of the Affects, Nowy Jork-Londyn 2004.

13 M. Cifor, Affecting relations..., s. 10. Więcej o zwrocie afektywnym zob. m.in.: P. Tincineto Clough, op.cit.

14 J. Surkis, When Was the Linguistic Turn? A Genealogy, „The American Historical Review” 2012, t. 117, z. 3, s. 700-722, DOI: 10.1086/ahr.117.3.700 [dostęp: 23.07.2021].

15 K. Nash, The 'Cultural Turn' in Social Theory: Towards a Theory of Cultural Politics, „Sociology” 2001, t. 35, z. 1, s. 77-92.

16 J. Guldi, What is the Spatial Turn?, https://spatial.scholarslab.org/spatial-turn/what-is-the-spatial-turn/, [dostęp: 23.07.2021].

17 Material Powers: Cultural Studies, History and the Material Turn, red. T. Bennett, P. Joyce, Nowy Jork 2010.

18 J. Żylińska, op.cit., s. 49.

19 B. Massumi, The Autonomy of Affect, „Cultural Critique” 1995, t. 31, z. 2, s. 83-109, DOI: 10.2307/1354446 [dostęp: 23.07.2021].

20 E. Kosofsky Sedgwick, A. Frank, Shame in the Cybernetic Fold: Reading Silvan Tomkins, „Critical Inquiry" 1995, t. 21, z. 2, s. 496-522. 
fleksja filozoficzna dotycząca emocji przed krytyką nowoczesności definiuje je jako opozycję do rozumu, symptom buntu ciała przeciwko rozumowi ${ }^{21}$.

Zaczęło się już w czasach przedplatońskich. Demokryt uważał, że mądrość uwalniać ma duszę od afektów, podobnie jak medycyna leczy ciało; afekt jest więc chorobą duszy, stojącą na przeszkodzie cnotom. Stoicy zalecali bezwzględną kontrolę afektów, które powodują błędne podejmowanie decyzji i nieracjonalne („nierozumowe") działania. Według stoików szczególnie preferowanym stanem była apatia - wyzwolenie się spod władzy wszelkich afektów. Bezwzględnie z emocjami rozprawił się Platon - w jego filozofii afekty były szkodliwe, prowadzące do nieokiełznania i zepsucia duszy. Nie stanowiły również składnika natury ludzkiej - ten status przynależny był jedynie rozumowi. Nawet platońska miłość miała być idealna i czysta duchowo, a nie cielesna i zmysłowa, a więc afektywna. Arystoteles, choć wobec afektów mniej okrutny niż Platon, wiązał afekty ze zmysłową (zwierzęcą) częścią duszy i nakazywał ich uważne kontrolowanie. Św. Augustyn nazywał afekty „niepokojami duszy” i upatrywał ich źródła w grzesznej naturze człowieka. Św. Tomasz z Akwinu twierdził, że hołdowanie afektom upodabnia człowieka do zwierzęcia. Erazm z Rotterdamu ogłosił wręcz krucjatę przeciwko afektom (szczególnie żądzy i gniewowi) głosząc, że podporządkowanie się im grozi życiem w ustawicznym niepokoju. Oświecenie, jako wiek rozumu, ugruntowało tylko wizerunek afektów jako wrogów racjonalnego myślenia. Fakt, iż Baruch Spinoza poświęcił afektom wiele miejsca w swojej Etyce, bynajmniej afektów wielce nie nobilitował; filozof zatytułował bowiem tę część swoich rozważań „O niewoli ludzkiej, czyli o siłach afektów”. Kartezjusz, postrzegający człowieka jako biologiczny mechanizm („ciało myślące”), również i sferę zmysłową czy afektywną widział przez pryzmat racjonalizacji i sprowadzał ją do sprawnie (lub niesprawnie) działającego mechanizmu. Nad afektami władzę miał sprawować rozum podobnie jak nad ciałem - i miał być to rozum silny. Ustawiczne uczuciowe uniesienia uważał za domenę rozumów słabych. Thomas Hobbes widział afekty jako „zaburzenia umysłu”, przeszkodę dla poznania rozumowego. Immanuel Kant dowodził, iż stany afektywne są efektem braku namysłu i zalecał opanowanie w uczuciach, będących przeszkodą dla życia czystego i duchowego. Ponowocześni filozofowie zdecydowanie zerwali z racjonalistycznym pojmowaniem afektu jako „przeszkody dla rozumu”, co zwiastowało erę emancypacji afektywności. W systemie filozoficznym zarówno Fryderyka Nietzschego, jak i Jacquesa Derri-

21 M.P. Markowski, op.cit., s. 354-356. 
dy afektywny potencjał ciała miał wspierać „rozsadzanie od wewnątrz” opartych na binarnych opozycjach systemów metafizycznych. Od tego momentu filozofia miała mieć bardziej „ludzki” wymiar, z wszystkimi człowieka przymiotami, nierozerwalnie związanymi z jego naturą - a więc również z ciałem i afektami. Jacques Lacan używał w tym celu metafory wstęgi Möbiusa, w której afekt i rozum połączone są w nierozerwalnym splocie. Pod takie podejście podwaliny położył wcześniejszy antykartezjański przewrót Freuda, nietzscheańskie uznanie podmiotu za jedność psychofizyczną i heideggerowskie postrzeganie afektów jako form „bycia właściwego”. Współcześni filozofowie przyznający afektom ważne miejsce w swoich systemach to m.in. Gilles Deleuze i Félix Guattari (teoria afektu jako mechanizmu przepływu intensywności i koncepcja dzieła sztuki jako bloku afektów i perceptów), Jean-François Lyotard (ekonomia libidynalna), Richard Rorty (projekt etyki wrażliwości), wspomniany już powyżej Jacques Derrida (etyka gościnności), Roland Barthes (rozważania nad etyką przyjemności) i wielu innych ${ }^{22}$.

Dla dwudziestowiecznej interdyscyplinarnej dyskusji o emocjach wyróżnić można dwie szkoły: naturalistyczną i kulturalistyczną.

Podejście naturalistyczne zakłada, że emocje powstają i są uwidaczniane wyłącznie na poziomie biologicznym - produkowane są przez określone partie mózgu (ciało migdałowate) i są pierwotne wobec jakichkolwiek kulturowych uwarunkowań. Emocje podstawowe (gniew, radość, smutek, zdziwienie, lęk, wstręt) mają według naturalistów charakter wrodzony, występują we wszystkich kulturach i są zawsze tak samo wyrażane.

„Z punktu widzenia współczesnej neuroscience, emocje to złożone zbiory chemicznych i neuronowych reakcji danego organizmu na bodźce zewnętrzne, uzależnione od wrodzonych mechanizmów zachodzących w ośrodku podkorowym mózgu i rozwiniętych w trakcie długiej historii ewolucyjnej. Emocje, powiadają neurokognitywiści, należą do ludzkiej natury (i być może nawet ją tworzą) i występują mniej więcej w takiej samej postaci, niezależnie od kulturowych uwarunkowań”23.

Odmienne jest na ten temat zdanie przedstawicieli szkoły kulturalistycznej (inaczej nazywanej konstruktywistyczną). Zgodnie z tym podejściem emocje, a w szczególności ich wyrazy, zależne są od kontekstu kulturowego i nie mają charakteru wrodzonego, ale nabyty wraz z socjalizacją. Emocje są umotywowa- 
ne kulturowo, w różnych kulturowych kontekstach powstają na różne sposoby i mają różne znaczenia, co prowadzi do wniosku że, wbrew podejściu naturalistycznemu, emocje nie są fenomenem uniwersalnym: „emocje są zachowaniami cielesnymi, ale jako takie podlegają społecznej kodyfikacji i wpisują się w «system afektywny» charakterystyczny dla danej kultury" ${ }^{24}$.

Krótko należy w tym miejscu zaznaczyć, że właściwie wszystkie badania z zakresu afektywności w kontekście archiwistyki dzieją się w nurcie kulturalistycznym, co nawiązuje do tradycji badań takich dyscyplin jak etnologia i antropologia kulturowa, kulturoznawstwo, socjologia czy historia.

Korpus literatury naukowej na temat afektywności archiwów (z perspektywy archiwistyki) nie jest jeszcze zbyt obszerny. Studia dotyczące bezpośrednio tego tematu pochodzą zazwyczaj z ostatnich kilku lat (choć wokół tej tematyki obraca się pośrednio wiele nieco wcześniejszych prac z zakresu takich tematów jak wpływ społeczny archiwów, sprawiedliwość społeczna, prawa człowieka, archiwa społeczne). Za szczególne kamienie milowe uznać można zorganizowaną w 2014 r. w Los Angeles konferencję naukową pt. „Afekt i archiwum” (w ramach serii sympozjów Archiwów Praw Człowieka przy Uniwersytecie Kalifornijskim Los Angeles) ${ }^{25}$ oraz wydany w 2016 r. tematyczny numer „Archival Science” zawierający część referatów wygłoszonych w trakcie konferencji ${ }^{26}$.

W artykule nie planuję jednak przeprowadzić kompleksowej analizy wszystkich naukowych tekstów napisanych do tej pory na temat afektów i archiwów, ale wskazać te obszary, które mogą być, w mojej opinii, najbardziej podatne na zastosowanie na rodzimym gruncie, oraz wskazuję te teksty, które wydają się być w tym nurcie najważniejsze i najbardziej interesujące. Szczególna waga przywiązana została do kwestii wartościowania dokumentacji.

Temat gromadzenia zasobu archiwalnego, a w szczególności selekcji archiwalnej, a więc dokonania wyboru tego, co ma się znaleźć w archiwach historycznych ze statusem źródeł przechowywanych wieczyście, jest wciąż bardzo ważnym zagadnieniem dla archiwistyki jako nauki, ale również jako dziedziny praktycznej działalności archiwów ${ }^{27}$. Tradycyjnie (modernistycznie) postrzegana selekcja ar-

24 Ibidem, s. 348.

25 Affect and the Archive: Program, https://affectandthearchive.wordpress.com/affect-and-the-archive/program/ [dostęp: 30.07.2021].

26 „Archival Science” 2016, t. 16.

27 R. Degen, Garść uwag na temat selekcji w Polsce, [w:] Archiwistyka na uniwersytetach, archiwistyka w archiwach, Toruńskie Konfrontacje Archiwalne, t. 1, red. W. Chorążyczewski, A. Rosa, Toruń 
chiwalna ma zapewnić dla przyszłych pokoleń korpus źródeł historycznych, które w sposób pełny i obiektywny przedstawiają przeszłość, a źródła te mają zostać wytypowane w procesie selekcji, która ma charakter naukowy i uniwersalistycz$n^{28}$. Jak słusznie zauważa w swoim podręczniku Waldemar Chorążyczewski:

„Trzeba od razu zaznaczyć, że to podejście «obiektywistyczne» stoi w sprzeczności z nowoczesnymi trendami kulturowymi, które na naszych oczach przenicowują całą humanistykę, przecząc nawet jej naukowości, a już na pewno obiektywności. Nie istnieje żaden obiektywny obraz rzeczywistości, a jedynie subiektywne konstrukcje, do których zalicza się zarówno źródła historyczne (czyli też zasób archiwalny), jak i dzieła historyków czy badaczy przyznających się do innych dyscyplin. Na gruncie postmodernistycznego subiektywizmu powstać może jednak zupełnie inna archiwistyka"29.

Halina Robótka w trakcie XVII Powszechnego Zjazdu Historyków Polskich w Krakowie (2004) zauważyła, że archiwista (stosujący metody i narzędzia selekcji) jest jednym z trzech czynników (obok kryteriów oraz zasad i metod selekcji) wpływających na to, jakie materiały uzyskają status wieczyście przechowywanych, a jakie ulegną zniszczeniu ${ }^{30}$. $Z$ badań Roberta Degena wiemy, że przed II wojną światową nie tylko archiwiści, ale również urzędnicy (pracownicy merytoryczni) mieli w pewnym stopniu wpływ na to, co ma zostać zachowane wieczyście. Sytuacja ta zmieniła się w okresie powojennym i trwa do dziś, kiedy ciężar podejmowania tych decyzji spoczął na archiwistach ${ }^{31}$. Wiedza o tym, że selekcja w archiwach państwowych, oprócz pewnych odgórnych, biurokratycznych mechanizmów (zresztą, niezadowalających) ${ }^{32}$, do pewnego stopnia podlega (a także

2009, s. 133-143; A. Górak, D. Magier, Selekcja archiwalna jako konstruowanie zasobu źródeł historycznych, „Archiwa - Kancelarie - Zbiory” 2011, nr 2 (4), s. 131-143.

Szczegółową krytykę tradycyjnego wartościowania archiwalnego przedstawia M. Caswell: eadem, Dusting for Fingerprints: Introducing Feminist Standpoint Appraisal, „Journal of Critical Library and Information Studies" 2019, t. 3, z. 1, s. 14-22, https://journals.litwinbooks.com/ index.php/jclis/article/view/113/67 [dostęp: 23.07.2021].

W. Chorążyczewski, Archiwistyka dla poczq̨tkujacych, Toruń 2014, s. 31, https://repozytorium. umk.pl/handle/item/2191 [dostęp: 1.08.2021].

30 H. Robótka, Zasady i metody selekcji dokumentacji tradycyjnej i elektronicznej a potrzeby badań obecnych i przyszłych, https://docplayer.pl/11414229-Zasady-i-metody-selekcji-dokumentacji-tradycyjnej-i-elektronicznej-a-potrzeby-badan-obecnych-i-przyszlych.html [dostęp: 31.07.2021].

31 R. Degen, Urzędnicy, selekcja i brakowanie dokumentacji w Polsce w XX wieku, [w:] Dzieje biurokracji na ziemiach polskich, red. A. Górak, K. Latawiec, D. Magier, t. 3, Lublin-Siedlce 2010, s. 545555.

32 W. Kwiatkowska, Co mogq, a co powinny wiedzieć o naszych czasach przyszłe pokolenia. Kulturowe aspekty selekcji dokumentacji, „Archeion” 2011, t. 112, s. 191-204; A. Górak, D. Magier, op.cit. 
podlegała) również konkretnym, osobistym decyzjom osób w nią zaangażowanych jest już w polskiej archiwistyce obecna. Żadne z polskich badań nie podejmuje jednak zagadnienia mechanizmów selekcji w perspektywie afektywnej - to znaczy przyjmując jako podstawowe założenie, że proces decyzyjny człowieka nie jest wolny od subiektywności i czynnika emocjonalnego ${ }^{33}$.

Takie założenie przyjmuje m.in. M. Cifor w swojej wprowadzającej do tematyki afektu i archiwów pracy z 2016 r. Ta kluczowa obecnie dla afektywności archiwów badaczka, odwołując się do krytyki tradycyjnych praktyk archiwalnych wynikającej z podejścia postmodernistycznego i badania archiwów społecznych, postuluje stosowanie wartości afektywnej jako prawomocnego kryterium selekcji archiwalnej ${ }^{34}$. Postulat ten bazuje na założeniu, iż proces selekcji nie polega na poszukiwaniu w źródłach archiwalnych wartości, lecz na nadawaniu im tejże wartości - i taka właśnie jest w nim rola archiwisty. Co więcej, archiwista podejmuje decyzje w konkretnym kontekście, posiadając jakieś wartości, cechy charakteru, przeświadczenia, opinie ${ }^{35}$. Wyłączenie czy ograniczenie osobistych sądów jest niemożliwe. Ponadto podejście to zakłada, że afektywne właściwości selekcji archiwalnej są (lub mogą być) pożądane: „wartość afektywna powinna wyjść na powierzchnię i wyraźnie być zastosowana jako kryterium selekcji” ${ }^{36}$. M. Cifor buduje swoją teorię, wykorzystując klasyczną już pracę Ann Cvetkovich An Archive of Feelings (Archiwum uczuć) z 2003 r. na temat afektów i archiwów queerowych, która stanowi interesujące (i bardzo wczesne, biorąc pod uwagę rozwój archiwistyki w tym kierunku) rozpatrywanie afektywnej mocy archiwów (w szerokim rozumieniu) ${ }^{37}$. Według A. Cvetkovich wszystkie teksty kultury (w tym i materiały archiwalne) są repozytoriami (znane nam słowo) uczuć i emocji - afekty są więc w nich immanentnie zakodowane. Co więcej, są z nimi również związane afektywne aspekty ich tworzenia i odbioru czy wykorzystania. Afektywna wartość może powstawać (czy też być nadawana) na różnych etapach tworzenia i wykorzystania dokumentu ${ }^{38}$.

Ponieważ teoria ta powstała na gruncie archiwów queerowych, może wydawać się nieadekwatna do innych typów archiwów. Jest to jednak zbytnie uprosz-

33 M.P. Markowski, op.cit., s. 353-354.

34 M. Cifor, Affecting Relations..., s. 13.

35 V. Harris, The archival sliver: power, memory and archives in South Africa, „Archival Science” 2002, t. 2, z. 1-2, s. 63-86.

36 M. Cifor, Affecting Relations..., s. 9.

37 A. Cvetkovich, An Archive of Feelings, Durham 2003.

38 M. Cifor, Affecting Relations..., s. 13-14. 
czenie. Rzeczywiście, archiwa queerowe wykazują się dość dużą specyfiką. Dokumentują różnie definiowaną przez siebie społeczność opartą na, upraszczając, nieheteronormatywności. Co charakterystyczne w przypadku tych archiwów, często (jako archiwa mniejszości) opowiadają historię inności, obcości, traumy, strachu i utraty, ale również intymności, seksualności (jako czynnika konstytuującego społeczność), radości, miłości. Są często „przeciw-archiwami” - występującymi przeciwko archiwalnemu i historycznemu głównemu nurtowi opowiadania o przeszłości. Te wszystkie cechy sprawiają, że archiwa społeczności LGBT+ są bardzo emocjonalne w swoich założeniach, ale również zbierane przez nie materiały mają ogromny potencjał afektywny, prezentując z bliska doświadczenia osobiste, niekiedy intymne - zarówno pozytywne, jak i negatywne. Doczekały się zresztą wielu publikacji naukowych z zakresu archiwistyki i nie tylko ${ }^{39}$. Archiwa queerowe, podobnie jak inne przykłady archiwów społecznych czy też archiwów społeczności, wychodzą poza tradycyjne rozumienie materiałów archiwalnych oraz archiwum. Często w ich zbiorach znajdują się materiały nieuznawane tradycyjnie za archiwalne, jak np. wlepki, piny, ziny, czasopisma, ulotki, dzieła sztuki, przedmioty, transparenty, pornografia i wiele innych.

To m.in. badania archiwów społecznych przyczyniły się w ostatnim dwudziestoleciu do przeformułowania poglądu na selekcję archiwalną nie jako na obiektywne poszukiwanie uniwersalnej wartości historycznej, godnej wieczystego zachowania dla przyszłych pokoleń historyków, ale jako na subiektywne, również emocjonalne, nadawanie źródłom partykularnej wartości dla konkretnej społeczności, w tym wartości afektywnej. ${ }^{40}$

39 Na przykład: D. Wakimoto, C. Bruce, H. Partridge, Archivist as Activist: Lessons from Three Queer Community Archives in California, „Archival Science” 2013, t. 13, z. 4, s. 293-316, DOI: 10.1007/ s10502-013-9201-1 [dostęp: 23.07.2021]. A. X, T. Campbell, M. Stevens, Love and Lubrication in the Archives, or rukus!: A Black Queer Archive for the United Kingdom, „Archivaria” 2010, t. 68, s. 271-94, https://archivaria.ca/index.php/archivaria/article/view/13240 [dostęp; 23.07.2021]; D. Marshall, The Queer Archive: Teaching and Learning Sexualities in Australia, "Transformations: The Journal of Inclusive Scholarship and Pedagogy” 2010/2011, t. 21, z. 2, s. 36-46; R. Taves Sheffield, Documenting Rebellions: A Study of Four Lesbian and Gay Archives in Queer Times, Sacramento 2020; E.H. Brown, Archival Activism, Symbolic Annihilation, and the LGBTQ2+ Community Archive, „Archivaria” 2020, t. 89, s. 6-33, https://archivaria.ca/index.php/ archivaria/article/view/13729 [dostęp: 23.07.2021]; D. Cooper, House proud: an ethnography of the BC Gay and Lesbian Archives, „Archival Science” 2016, t. 16, z. 3, s. 261-288, DOI: 10.1007/ s10502-015-9250-8 [dostęp: 23.07.2021].

40 A. Flinn, Archival activism: independent and community-led archives, radical public history and the heritage professions, „InterActions” 2011, t. 7, z. 2, DOI: 10.5070/D472000699 [dostęp: 23.07.2021]. 
Jest to truizm, ale taki, który chyba należy tutaj z całą mocą umiejscowić: różne typy archiwów w różny sposób gromadzą swoje zasoby archiwalne. Archiwa społeczne i archiwa prywatne, a więc te, które mają największe znaczenie w dyskusji na temat afektywnych aspektów selekcji archiwalnej, gromadzą swój zasób całkowicie odmiennie od archiwów państwowych, w efekcie - bardzo odmienne są w nich mechanizmy selekcji.

Archiwa społeczne nie posiadają prawnie ustalonego przedpola archiwalnego (choć oczywiście jakieś, niesformalizowane, przedpole mają). Ich aktotwórcy nie używają oficjalnych wykazów akt z kategorią archiwalną. Gromadzenie w archiwach społecznych polega w dużej mierze na osobistych kontaktach archiwistów ze społecznością, które owocują darowiznami lub możliwością współpracy przy wywoływaniu źródeł (zwł. nagrań historii mówionej). Selekcja archiwalna, choć niesformalizowana, również jest prowadzona. Nie przyjmują przecież archiwa społeczne wszystkich materiałów, na które kiedykolwiek i gdziekolwiek natrafią. Najczęściej stosowanym kryterium selekcji jest zgodność z tematem archiwum (jest to kryterium stosowane zarówno na etapie selekcji aktotwórców, jak i selekcji dokumentacji). Można podejrzewać, że w pewnej formie (jak podkreśliłam, w ogromnej większości niesformalizowanej, a nawet nieuświadomionej), archiwa społeczne powielają kryteria selekcji znane z literatury przedmiotu, jak na przykład kryterium dawności, unikatowości, niepowtarzalności informacji (niekoniecznie niepowtarzalności tekstów), być może również kryterium typowości. Niekiedy kryterium jest typ źródła czy rodzaj dokumentu (np. fotografie, historia mówiona), a także sposób zapisu (np. decyzja o gromadzeniu wyłącznie danych cyfrowych podjęta ze względów praktycznych). Ponieważ jednak szczegółowe studia na ten temat nie były prowadzone, pozostają te twierdzenia w formie przypuszczeń (oraz postulatu badawczego), opartych na dotychczasowych badaniach i znajomości zjawiska społecznych archiwów ${ }^{41}$.

Bardzo interesujące jest również zagadnienie konstruowania archiwum osobistego oraz rodzinnego. Konstruowania, a więc nadawania wartości i znaczeń,

41 O gromadzeniu w archiwach społecznych w Polsce zob. np.: A. Jóźwik, N. Martini, Realia funkcjonowania archiwów społecznych i czynniki sprzyjajace ich rozwojowi, [w:] Archiwistyka społeczna. Diagnoza i wyzwania, praca zbiorowa, Warszawa 2017, s. 69-70, https://cas.org.pl/wp-content/ uploads/2021/03/archiwistyka-spoleczna-diagnoza-i-wyzwania.pdf [dostęp: 23.07.2021]; M. Wiśniewska-Drewniak, Inaczej to zniknie. Archiwa społeczne w Polsce - wielokrotne studium przypadku, Toruń 2019, sekcja 11 w rozdziałach 4-11 oraz s. 571-573. 
czyli de facto również dokonywania selekcji archiwalnej, często wielokrotnej, powtarzanej przy różnych okazjach i na różnych etapach życia, a w przypadku archiwów przekazywanych z pokolenia na pokolenie - dokonywanej przez różne osoby $^{42}$. Archiwa osobiste, rodzinne i rodowe często stawały się przedmiotem badań archiwistów i historyków, również w kontekście konstruowania pamięci i tożsamości ${ }^{43}$. Właściwie zawsze badania te dotyczyły archiwów jako materialnych pozostałości po przeszłych twórcach i stosowały metody oparte na analizie materiałów archiwalnych. Bardzo interesującym zagadnieniem jest badanie archiwów prywatnych tu i teraz, kiedy mamy dostęp nie tylko do efektu działań konstruowania archiwum, ale również do osoby czy osób, które podejmują te kluczowe z punktu widzenia selekcji archiwalnej decyzje. Dlaczego twórca archiwum decyduje się zachować jakieś dokumenty, a zniszczyć inne? Czy z czasem zmienia te decyzje? Jak definiuje wartość? Jak wykorzystuje za swojego życia archiwum osobiste lub rodzinne i jak sposoby jego wykorzystania rzutują na decyzję o nadawaniu dokumentacji wartości? Czy emocjonalna reakcja na dokument lub to, co zapisuje, zarówno negatywna, jak i pozytywna, wpływa na decyzję o jego zachowaniu? Komu w przyszłości służyć ma to archiwum? Jakie znaczenie w kształtowaniu własnego archiwum ma twórcy wykształcenie, doświadczenia, pochodzenie, świadomość dokumentacyjna, wiedza na temat archiwów?

To ostatnie pytanie zadali sobie $\mathrm{w}$ niedawnych badaniach członkowie chińskiego zespołu z Uniwersytetu Yunnan i Uniwersytetu Seczuańskiego. Badacze przeprowadzili 21 wywiadów pogłębionych $\mathrm{z}$ archiwistami na temat tego, w jaki sposób tworzą swoje własne, osobiste archiwa i jak stosują w tym wypadku wiedzę z zakresu archiwistyki ${ }^{44}$.

Innym przykładem bardzo interesujących badań z zakresu współcześnie tworzonych archiwów osobistych, do tego podejmujące w znacznej mierze tematykę ich afektywności, jest artykuł opublikowany niedawno w czasopiśmie „Archivaria”45. Jennifer Douglas i Alexandra Alisauskas zbadały role pełnione

42 C. Hobbs, The Character of Personal Archives: Reflections on the Value of Records of Individuals, „Archivaria” 2001, t. 52, s. 126-135.

43 Zob. np.: W. Chorążyczewski, S. Roszak, Pamięć rodu Komierowskich, Torun 2002.

44 T. Huang, R. Nie, Y. Zhao, Archival knowledge in the field of personal archiving: an exploratory study based on grounded theory, ,Journal of Documentation” 2021, t. 77, z. 1, s. 19-40, DOI: 10.1108/ JD-04-2020-0071 [dostęp: 23.07.2021].

45 J. Douglas, A. Alisauskas, It Feels Like a Life's Work-Recordkeeping as an Act of Love, „Archivaria” 2021, t. 91, s. 6-37. 
przez zapis ${ }^{46} \mathrm{w}$ życiu ośmiu matek, które straciły swoje dzieci w niedługim czasie po ich urodzeniu. W badaniu zastosowano metodę wywiadu częściowo ustrukturyzowanego. Badaczki zwróciły również uwagę na to, jak tak osobisty temat badań wpływa na osoby udzielające wywiadu, w jaki sposób stanowi on dla nich ulgę w cierpieniu, a na ile może to cierpienie powodować, prowadzić do ponownego otwarcia ran i przypominania traumy. Badaczki wskazują, że osoby udzielające wywiadu pozytywnie odbierały proces badawczy, jako możliwość podzielenia się swoim cierpieniem ${ }^{47}$. Afektywnie naładowany jest w tym wypadku nie tylko temat badań (żal, żałoba), ale również sam proces badawczy. Zapisy, które stawały się archiwami utraconych dzieci, mogły mieć formę bardziej lub mniej zbliżoną do dokumentu, np. dokumentacja medyczna, w tym obrazy ultrasonograficzne, biżuteria z wygrawerowanym imieniem lub inicjałem imienia dziecka, fotografie, ubrania, odciski dłoni i stóp, kosmyki włosów, różnego typu przedmioty. Informatorki w swoich wypowiedziach wskazywały na różne sposoby nadawania wartości tym zapisom. Jednym z wymienianych przez informatorki powodów dla zatrzymania jakiegoś zapisu był sam fakt, że ich dziecko miało fizyczny kontakt z jakimś przedmiotem: „uczestnicy wspominali, jak cenne jest dla nich wszystko, co dotykało lub w inny sposób było połączone z ciałami ich dzieci i jak te rzeczy - ubrania, kocyki dziecięce, odciski dłoni i stóp, kosmyki włosów, skremowane szczątki ich dzieci stały się znaczącymi zapisami jako dowody fizycznej obecności ich dzieci"48.

Utrata bliskiej osoby, w tym wypadku nowonarodzonego dziecka, i tworzenie jej archiwum to dość skrajny i specyficzny przypadek podejmowania subiektywnej i emocjonalnie umotywowanej decyzji co do selekcji archiwalnej. Przy czym mam na myśli „skrajność i specyfikę” w sensie bezprecedensowości tego typu badań w naszej dziedzinie, nie w kontekście prawdziwego życia, bo w nim takie decyzje są podejmowane przez niektóre rodziny na co dzień.

Należy zwrócić jednak uwagę na to, że również w archiwach państwowych archiwiści podejmują konkretne decyzje na temat tego, co ma wieczystą wartość (i już nigdy nie ma zostać intencjonalnie zniszczone), a co tej wartości nie ma - i należy (czy raczej można) się tego pozbyć, ponieważ nigdy nie będzie już potrzebne przyszłym pokoleniom. Takimi sytuacjami są np. ekspertyzy ar-

46 W oryg. records rozumiane bardzo szeroko, zarówno jako dokumenty (zapisy informacji), jak również przedmioty (np. pluszaki, kamyki, suszone kwiaty); J. Douglas, A. Alisauskas, op.cit., s. 15.

47 Ibidem, s. 9.

48 Ibidem, s. 18. 
chiwalne w przypadku dokumentacji o kategorii BE oraz wydawanie zgód na brakowanie. Szczególną sytuacją jest kontakt z potencjalnym dostarczycielem zasobu spoza jednostek pod nadzorem archiwalnym, czyli na przykład z rodziną osoby, która miałaby wytworzyć i zgromadzić w trakcie swojego życia cenne materiały. Dziać się tak może w przypadku, gdy do archiwum samodzielnie zgłasza się darczyńca lub jego potomkowie i spadkobiercy, lub gdy archiwum samodzielnie podejmuje się takiego kontaktu. Również zainicjowane w ostatnich latach przez Naczelną Dyrekcję Archiwów Państwowych projekty dokumentacyjne, polegające na otwartych wezwaniach do przekazywania do archiwów państwowych swoich materiałów archiwalnych ${ }^{49}$, generują ogromne pole dla różnorodnych decyzji archiwistów. Kto jest osobą na tyle ważną, że warto zachować jego materiały? Jakie materiały są godne zachowania? Na jakich zasadach w obu przypadkach (tj. na obu poziomach selekcji) nadaje się wartość i ważność selekcjonowanym obiektom?

Do pewnego stopnia i tutaj można zestandaryzować proces dokonywania oceny wartości najpierw aktotwórcy, a potem akt (zgodnie z przyjętymi zasadami selekcji archiwalnej). Nawet najbardziej szczegółowe wytyczne dadzą jednak tylko złudną nadzieję, że proces będzie obiektywny, naukowy i bezstronny, a każdy archiwista, dzięki wytycznym, podjąłby co do wartościowania taką samą decyzję. Finalnie decyzję i tak osobiście podejmować będzie archiwista. Postmodernistyczna archiwistyka dawno już pożegnała $\operatorname{się}^{50} \mathrm{z}$ możliwością, aby archiwista wyzbył się swoich własnych cech osobowych i przekonań, co dobitnie podkreślała już 10 lat temu Wiesława Kwiatkowska:

„Można śmiało powiedzieć, że archiwista nigdy nie jest bezstronnym sędzią, który na podstawie obiektywnych, tzn. niezależnych od niego, jedynie słusznych (bo naukowych) zasad dokonuje selekcji akt, ich gromadzenia, opracowania i udostępnienia. Archiwa i ich pracownicy są częścią współczesności, współczesnej kultury i społeczeństwa. Stąd czerpią swoją wizję i swoje poglądy zarówno na temat przeszłości, jak i teraźniejszości, zatem czasów, w których zostały i są wytworzone akta" ${ }^{\prime 1}$.

49 Mowa tu o projektach z serii „Archiwa Rodzinne” oraz „Archiwum Pandemii”.

50

Porównaj obronę modernizmu i obiektywizmu Luciany Duranti: eadem, The Concept of Appraisal and Archival Theory, „The American Archivist” 1994, t. 57, z. 2, s. 328-244.

51 W. Kwiatkowska, op.cit., s. 192. Zob. też: S. Schoenebeck, P. Conway, Data and Power: Archival Appraisal Theory as a Framework for Data Preservation, „Proceedings of the ACM on HumanComputer Interaction" 2020, t. 4, z. CSCW2, art. nr 162, s. 1-18, DOI: $10.1145 / 3415233$ [dostęp: 23.07.2021]. 
Tę postulowaną obiektywność archiwisty nazywa M. Caswell „oglądem znikąd" i zauważa, że zgodnie z tym założeniem archiwista miał się z podejmowania wartościujących akta decyzji „samousunąć”. Ze zdziwieniem M. Caswell pyta: „Jak to się dzieje, że dominujący zachodni kanon literatury na temat selekcji w XX wieku ignoruje lub dewaluuje stanowisko archiwisty? Jak to się dzieje, że nawet w ciągu ostatnich dwudziestu lat, kiedy dominujący teoretycy archiwistyki uznali podmiotowość archiwisty, jego pozycjonowanie ${ }^{52}$ jest w dużej mierze postrzegane jako coś, co należy dokumentować i łagodzić, a nie akceptować?" 53 .

Warto pamiętać, że M. Caswell jest przedstawicielką archiwistyki radykalnej: po pierwsze, świadomej, że archiwa należą do władzy i są instrumentami władzy - to jest wykonywania władztwa silniejszych nad słabszymi ${ }^{54}$; po drugie, archiwistyki dążącej do zmiany w świecie (przede wszystkim takiej zmiany, która ma zadośćuczynić osobom marginalizowanym i do tej pory pomijanym lub niestosownie reprezentowanym przez archiwa, czyli takim grupom, które nie miały i nie mają władzy). M. Caswell wzywa do wykorzystywania przez archiwistów swojego pozycjonowania, aby walczyć z "duchami” wciąż nawiedzającymi amerykańskie (ale też australijskie, kanadyjskie czy brytyjskie) archiwa, jak rasistowski język opisu, brak reprezentacji społeczności innych niż białe, nadreprezentacja elit i mężczyzn. Co więcej, badaczka jasno wskazuje, że do walki archiwiści powinni zaprzęgnąć emocje: „[...] jednym ze sposobów, w jaki możemy działać przeciwko tym opresyjnym systemom, jest poważne traktowanie emocji w połączeniu z analizą władzy, uznanie ich za ważne podstawy wiedzy, ważne podstawy teorii i praktyki archiwalnej, a co najważniejsze, odnosić się do emocji w relacji nie tylko do naszego życia osobistego, ale także do dominujących opresyjnych struktur władzy. Nasze emocje, podczas gdy doświadczamy ich na poziomie osobistym, są głęboko polityczne i można je wykorzystać do zmian strukturalnych"55.

52 W oryg. positionality - czyli np. pochodzenie, pogląd na świat, kontekst społeczny i polityczny, osobiste wartości i przekonania itd.

53 M. Caswell, Dusting for Fingerprints..., s. 6. Jako wyjątek M. Caswell podaje prace Verne'a Harrisa.

54 To jedno z podstawowych założeń archiwistyki postmodernistycznej. Zob.: J.M. Schwartz, T. Cook, Archives, records, and power: The making of modern memory, „Archival Science” 2002, t. 2, z. 1-2, s. 1-19, DOI: 10.1007/BF02435628 [dostęp: 23.07.2021]; T. Cook, J.M. Schwartz, Archives, records, and power: From (postmodern) theory to (archival) performance, „Archival Science" 2002, t. 2, z. 3-4, s. 171-185, DOI: 10.1007/BF02435620 [dostęp: 23.07.2021].

55 M. Caswell, Feeling Liberatory Memory Work: On the Archival Uses of Joy and Anger, „Archivaria” 2020, t. 90, s. 153, https://archivaria.ca/index.php/archivaria/article/view/13763 [dostęp: 23.07.2021] 
Co niemniej ważne, M. Caswell podkreśla, że to, iż archiwiści mają kierować się uczuciami, nie oznacza, że nie powinni kierować się faktami. Nie są to rzeczy rozbieżne ani opozycje - są to wartości, które się uzupełniają ${ }^{56}$.

Co to może oznaczać w praktyce w naszych rodzimych realiach? M. Cifor jasno zaznacza, że choć jej postulat stosowania kryterium afektywnego w wartościowaniu dokumentacji może przynieść pozytywne efekty zarówno dla teorii, jak i praktyki archiwalnej, nie musi on sprawdzać się dla każdego typu archiwum ${ }^{57}$.

Można jednak podejrzewać (to kolejne moje stwierdzenie o charakterze raczej tezy i postulatu badawczego), że kryterium afektywne (oraz estetyczne) już jest w pewnym stopniu praktycznie stosowane przez archiwistów. Być może archiwista społeczny chętniej (czy też wcześniej) poprosi o nagranie wspomnień starszą panią, znaną na osiedlu z tego, że pięknie opowiada swoim sąsiadkom historię z wojny, nie szczędząc opowieści strasznych, bolesnych, zabawnych. Być może archiwista rodzinny (czyli po prostu - człowiek) chętniej zatrzyma w swoim archiwum fotografię, o której nie wie, kto na niej jest, kto ją wykonał, ani kiedy, jeśli fotografia nie przedstawia nieznanego budynku, lecz nieznane dziecko, uśmiechnięte od ucha do ucha i pokazujące w grymasie ostatecznej radości wszystkie cztery zęby. Być może archiwista państwowy chętniej przyjmie darowiznę od potencjalnego darczyńcy, jeśli w jego dzienniku z pierwszych tygodni pandemicznego lockdownu wiosną 2020 r., oprócz przedstawienia suchych faktów z życia, znajdą się opisy tego, jak autor dziennika był niepewny o swoją pracę, swoje zdrowie i rodzinę, jak cieszył się z informacji, że spadła globalna emisja zanieczyszczeń, jak z przerażeniem czytał raporty o kolejnych objawach choroby, jak złościł się na to, że w sklepach są kolejki, a gdy już do jakiegoś sklepu się dostał - jakie zażenowanie (a może i niedowierzanie) odczuwał na widok pustych półek, na których jeszcze niedawno piętrzyły się zapasy papieru toaletowego. Takie konkretne (choć wyimaginowane) sytuacje pokazują, że być może brzmiące na początku przedziwnie i rewolucyjnie postulaty M. Cifor i M. Caswell wcale nie muszą być praktyce archiwalnej całkowicie obce, a zastosowanie kryterium emocjonalnego w wartościowaniu archiwów nie musi być dziwne, nieprofesjonalne czy rewolucyjne i nakierowanie na nadwątlenie białej supremacji.

Wartościowanie archiwaliów wymaga wzięcia pod uwagę tego, jak i przez kogo mają one zostać wykorzystane, czyli zasadniczo - czy faktycznie wyselekcjonowa-

56 Ibidem, s. 154-155.

57 M. Cifor, Affecting relations..., s. 16. 
ne materiały archiwalne będą w przyszłości przydatne. W ostatnich latach zmienił się znacząco profil użytkowników archiwów, szala z profesjonalnych historyków przesunęła się na stronę genealogów, historyków „nieprofesjonalnych” (pasjonatów historii), historyków rodzinnych, dziennikarzy, popularyzatorów historii itd. Niedawne badania Caryn Radick na temat wykorzystania archiwów przez pisarzy romansów wskazują, że takie osoby stosunkowo często sięgają do zasobów archiwów i bibliotek, podczas gdy profesjonalne user studies skupiają się głównie na naukowcach jako odbiorcach informacji zawartej w archiwach $^{58}$. Ten jednostkowy przypadek każe zastanowić się nad tym, czego użytkownicy w archiwach poszukują. Ilu z nich poszukuje tak szeroko obecnych w archiwach państwowych dla XX w. protokołów, raportów, podsumowań, analiz, sprawozdań, akt typowych instytucji wyższego szczebla, podstaw prawnych działania instytucji itd. ${ }^{59} \mathrm{Ilu}$ z nich bardziej interesują jednostkowe przykłady, konkretne sprawy, osoby, miejsca. Ilu nieprofesjonalnych (mam na myśli nienaukowych, spoza akademii) użytkowników trafia na przykład do serwisu Szukaj w archiwach, poszukując inspiracji dla wystroju wnętrz z lat 60., bo ktoś planuje wyposażyć mieszkanie w kamienicy tak, aby jak najwierniej oddawało klimat tamtego okresu (fantastycznego dla polskiego wzornictwa użytkowego)? Ilu z nich poszukuje fotografii ubrań z lat 90., bo popularna jest obecnie moda na retro i vintage? Albo pamiętników z okresu II wojny światowej do tworzonej przez siebie sztuki teatralnej? A może archiwalnych, estetycznych zdjęć psów nadających się do wydrukowania w dużym formacie i powieszenia w klinice weterynaryjnej? Jak często takie osoby odchodzą od monitora $z$ kwitkiem, a archiwiści nie wiedzą o tym, albowiem osoby takie nie trafiają nigdy do archiwum? W perspektywie nowego poglądu na selekcję warto również zauważyć, jak ważna w ostatnich latach stała się dla archiwów praca publiczna - a więc na przykład takie działania jak wystawy archiwalne (tradycyjne czy wirtualne), pokazy, wycieczki, gry miejskie, konkursy itd. ${ }^{60}$ Czy nie łatwiej byłoby organizować je i przyciągać do nich odbiorców (oraz angażować ich), gdyby zasoby archiwów były bardziej nakierowane na przedstawianie historii ludzi (a nie instytucji), gdyby zawierały więcej informacji partykularnych i pierwotnych (a nie wtórnych zbiorczych opracowań), gdyby angażowały odbiorców emocjonalnie - bo same materiały byłyby nośnikami emocji?

58 C. Radick, Romance Writers' Use of Archives, „Archivaria” 2016, t. 81, s. 45-73, https://archivaria.ca/index.php/archivaria/article/view/13558 [dostęp: 23.07.2021].

59 W. Kwiatkowska, op.cit.

60 A. Rosa, Funkcja edukacyjna archiwów, Warszawa 2012. 
Poziom emocjonalnego obciążenia materiałów archiwalnych w kontekście ich wykorzystania ma szczególne znaczenie w przypadku archiwów społecznych, które potencjalnie wykorzystują afektywność w swojej codziennej pracy, jak również gromadzą wiele typów źródeł mających duży ładunek afektywny, np. osobistych fotografii, przedmiotów życia codziennego, dzienników i pamiętników, korespondencji osobistej, a nade wszystko - nagrań historii mówionej. Te źródła są bardzo afektywne często same w sobie (bezpośrednio mówią o emocjach lub je przedstawiają), ale mają również afektywny kontekst, który zyskują w momencie ich wykorzystywania i w ten sposób „zwracania” społeczności (np. lokalnej). Przykładem może być utworzenie przez archiwum (razem z darczyńcami) wystawy archiwalnej umieszczonej w przestrzeni publicznej, dzięki której darczyńcy dzielą się ze społecznością swoimi historiami i wytworzonymi przez siebie dokumentami (lub historiami i dokumentami swoich przodków), które stają się waż$n e^{61}$.

Wykorzystanie archiwów to zresztą bardzo ważny i poruszany już w literaturze z zakresu archiwistyki aspekt ich afektywności. Przykładami mogą być bardzo interesujący artykuł Jamie A. Lee o cielesnym i afektywnym doświadczaniu archiwów ${ }^{62}$ lub M. Cifor o afektywnych implikacjach odnalezienia wśród materiałów archiwalnych ludzkiego włosa (co być może niektórym czytelnikom również się przydarzyło $)^{63}$. M. Cifor zwraca zresztą uwagę, że sam temat afektywnego wpływu archiwów na odbiorcę jest już obecny w literaturze dość szeroko, był jednak opisywany w szczególności z pozycji badacza używającego w swojej pracy archiwów ${ }^{64}$. Tutaj jednak obszary badawcze na styku afektu i archiwów wcale się nie kończą. Afektywne aspekty archiwów mogą przejawiać się również w opracowaniu archiwalnym, np. w budowaniu struktury archiwum i jego opisu (oraz wartościowania archiwaliów) wokół nienawiści ${ }^{65}$, jak również w statusie języka służącego opisowi

61 Zob. np. wystawa Bronowickiego Archiwum Społecznego: M. Wiśniewska-Drewniak, op.cit., s. 192-193; wystawa Opowiadaczy Historii Dolnego Miasta w Gdańsku: ibidem, s. 381-382; wystawy Obywatelskiego Archiwum Podkowy Leśnej: ibidem, s. 427-428.

62 J.A. Lee, Be/longing in the archival body: eros and the "Endearing” value of material lives, „Archival Science” 2016, t. 16, z. 1, s. 33-51, DOI: 10.1007/s10502-016-9264-x [dostęp: 23.07.2021].

63 M. Cifor, Presence, Absence, and Victoria's Hair: Examining Affect and Embodiment in Trans Archives, „Trangender Studies Quarterly” 2015, t. 2, z. 4, s. 645-649, DOI: 10.1215/232892523151565 [dostęp: 23.07.2021].

64 M. Cifor, Affecting relations..., s. 11.

65 M. Cifor, Aligning Bodies: Collecting, Arranging, and Describing Hatred for a Critical Queer Archives, „Library Trends” 2016, t. 64, z. 4, s. 756-775, https://www.ideals.illinois.edu/bitstream/ handle/2142/94939/64.4.cifor.pdf [dostęp: 23.07.2021]. 
archiwalnemu (języka rzekomo neutralnego, ale obecnie negatywnie odbieranego np. przez osoby z niepełnosprawnościami) ${ }^{66}$.

Tu niewielka nota marginalna: niestosowność języka opisu archiwalnego powinna zostać poddana ocenie również w Polsce. Dla zobrazowania sprawy podam tylko kilka przykładów autentycznych opisów archiwalnych z polskich archiwów, dostępnych w serwisie Szukaj w archiwach: „Murzyn i Murzynka chorzy na śpiączkę afrykańską”67, „Żołnierze niemieccy podczas rozmowy z Murzynami”68, „Reportaż o Cyganach - rozmowa z Cyganami na temat ich życia, obyczajów i folkloru”69 "Cygan z tresowanym niedźwiedziem na ulicy w Szczawnicy”70, „Szkoły dla dzieci upośledzonych” (nazwa serii) ${ }^{71}$, „Dzieci upośledzone” (również nazwa serii, a w niej m.in. jednostka o oryginalnym niemieckim tytule, który można przetłumaczyć na „Głuchoniemi, ślepi, idioci, jąkały”)"72. Oczywiście sprawa nie jest łatwa, a język jest przecież organizmem żywym i wciąż ewoluującym, poddającym się naciskom kultury. Czy to oznacza, że opis archiwalny nie jest wykonany raz na zawsze i powinien być co jakiś czas rewidowany? Jaka jest skala tego zjawiska? Czy oryginalne, nadane przez aktotwórcę opisy mają podlegać ingerencji ze względu na fakt, iż obecnie są obraźliwe, choć w przeszłości nie były? Czy możemy pozwolić na to, aby osoby, które najczęściej i tak są przez archiwa marginalizowane (np. mniejszości etniczne, seksualne, osoby z niepełnosprawnością), jeśli już znajdą odbicie swojej grupy tożsamościowej w archiwach, napotkają na obraźliwy język stosowany do ich opisu przez instytucję państwową i urząd wiary publicznej? To zestaw pytań tworzących kolejny już postulat badawczy - zbadanie zjawiska niestosowności języka opisu archiwalnego w Polsce.

Poruszony musi zostać jeszcze jeden bardzo interesujący obszar afektywności archiwów, tj. potencjał traumatyzujący archiwów. Chodzi, w uproszczeniu, o sytu-

66 G. Brilmyer, Archival assemblages: applying disability studies' political/relational model to archival description, „Archival Science” 2018, t. 18, z. 2, s. 95-118, DOI: 10.1007/s10502-018-9287-6 [dostęp: 23.07.2021].

67 Narodowe Archiwum Cyfrowe, 3/2/0 Wydawnictwo Prasowe Kraków-Warszawa 1939-1945, sygn. 3/2/0/-/15378.

68 Ibidem, sygn. 3/2/0/-/2066.

69 Ibidem, 3/33/0 Zbiór nagrań dźwiękowych 1889-2008, sygn. 3/33/0/2/4022.

70 Ibidem, 3/1/0 Koncern Ilustrowany Kurier Codzienny - Archiwum Ilustracji 1910-1939, Cygan z tresowanym niedźwiedziem na ulicy w Szczawnicy 1919-1930, sygn. 3/1/0/6/2322.

71 Archiwum Państwowe w Szczecinie, 65/73/0 Naczelne Prezydium Prowincji Pomorskiej w Szczecinie [1632] 1808-1945, seria 65/73/0/17.5.

72 Archiwum Państwowe w Katowicach Oddział w Pszczynie, 17/293/0 Powiatowy Inspektorat Szkolny w Pszczynie [1802] 1872-1922, seria 17/293/0/8. 
ację, gdy materiały archiwalne są emocjonalnie trudne dla archiwisty lub badacza, który się nimi zajmuje, zazwyczaj spędzając w ramach swojej pracy wiele godzin w kontakcie ze źródłami. O jakie sytuacje może chodzić? Na przykład o fotografie z okresu wojny dokumentujące ciała żołnierzy w okopach, umierające dzieci na ulicach getta, wyniszczonych więźniów obozów koncentracyjnych, dokumentację medyczną z tychże, wywiady historii mówionej poruszające traumatyczne przeżycia świadka, raporty z sekcji zwłok (wraz z dokumentacją fotograficzną), akta policyjne, sądowe dokumentacje wizji lokalnych, zeznania świadków w postępowaniach sądowych ${ }^{73}$, pamiętniki opisujące traumatyczne wydarzenia i wiele, wiele innych. Afektywna relacja między archiwistą a materiałem archiwalnym może być wyniszczająca i emocjonalnie trudna, zwłaszcza, gdy jest ona bagatelizowana, a archiwista (szczególnie młody i niedoświadczony) nie ma wsparcia we współpracownikach i przełożonych. Jest to problem natury nie tyle badawczej, co bardzo praktycznej, ale wymagający kompleksowego podejścia od strony nauki archiwalnej, jak również zaangażowania stowarzyszeń zawodowych ${ }^{74}$.

Powyższa, długa, a jednak częściowa tylko analiza dotychczasowych relacji pomiędzy archiwistyką a studiami afektywnymi pokazuje, jak szerokie może okazać się to pole do zagospodarowania dla badaczy dziedziny archiwalnej. Tematyka ta zdecydowanie i szybko zyskuje na popularności w krajach anglosaskich ${ }^{75}$. Warto postrzegać jednak powstanie tej teorii w kontekście, w którym uzyskała dla archiwistyki szczególne znaczenie, tj. zwłaszcza w świecie anglosaskim ostatnich kilku

73 Temat ten poruszono w trakcie spotkania Seminarium Badań Egodokumentalnych Uniwersytetu Mikołaja Kopernika w Toruniu w czerwcu 2021 r. przy okazji referatu dr. Jerzego Bednarka pt. „Ślady egodokumentalne w aktach wojskowych sądów rejonowych z lat 1946-1955” i emocjonalnego ciężaru badania wniosków o ułaskawienie osób skazanych na karę śmierci. ARA Emotional Support Guidelines, 2017, https://www.archives.org.uk/what-we-do/emotionalsupport-guides.html [dostęp: 1.08.2021]; N. Laurent, M. Hart, Emotional Labor and Archival Practice - Reflection, „Journal of the Society of North Carolina Archivists” 2018, t. 15, s. 13 22, http://www.ncarchivists.org/wp-content/uploads/2019/02/jsnca_vol15_laurent-hart-1. pdf [dostęp: 1.08.2021]; K. Sloan, J. Vanderfluit, J. Douglas, Not 'Just My Problem to Handle': Emerging Themes on Secondary Trauma and Archivists, „Journal of Contemporary Archival Studies" 2019, t. 6, https://elischolar.library.yale.edu/jcas/vol6/iss1/20/ [dostęp: 1.08.2021]; N. Laurent, K. Wright, A trauma-informed approach to managing archives: a new online course, „Archives and Manuscripts” 2020, t. 48, z. 1, s. 80-87, DOI: 10.1080/01576895.2019.1705170 [dostęp: 1.08.2021]; N. Laurent, M. Hart, Building a trauma-informed community of practice, „Education for Information” 2020, t. 37, z. 1, s. 1-6, DOI: 10.3233/efi-190363 [dostęp: 1.08.2021].

75 Zob. też projekt dotyczący archiwów i sztuki: Archivo Artea. Archivos de afectos, http://archivoartea.uclm.es/contextos/archivos-de-afectos/ [dostęp: 31.07.2021]. 
lat, w którym mają miejsca takie zjawiska jak: walka ze zinstytucjonalizowanym rasizmem i sprawa George’a Floyda (USA); ciągłe rozliczanie się z kolonialną przeszłością i krzywdami wyrządzonymi przez Europejczyków ludom autochtonicznym, a więc ciągłe tarcie na linii etnicznej potomkowie Europejczyków/potomkowie autochtonów (Kanada, Australia, USA); rosnąca popularność archiwów społeczności LGBT+ oraz współczesne teorie i zwroty naukowe oscylujące wokół tematyki m.in. gender studies, queer studies, feminizmu. Mimo popularności, zwłaszcza w tym kontekście społecznym i politycznym, jakże odmiennym od polskiego, również na naszym rodzimym gruncie spojrzenie na archiwa poprzez ich afektywność może mieć ciekawe i pożyteczne zastosowanie.

Afekt jako orientację badawczą łatwo zdyskredytować pod pozorem nienaukowości lub nieracjonalności; robiono to w zachodniej nauce i filozofii od bardzo dawna. Szczególnie trudne może być zaakceptowanie tego typu podejścia w archiwistyce - dyscyplinie „twardo stąpającej po ziemi”, immanentnie związanej z praktyką administracyjną i instytucjonalną; dyscyplinie, której narodziny mają charakter modernistyczny, ściśle racjonalistyczny i wciąż silnie związany z obiektywizmem; dyscyplinie na tyle młodej, o niekoniecznie rozpoznanej samodzielności, która nie poprzestaje w wysiłkach, aby udowodnić, że jest nauką o archiwach; dyscyplinie, która wciąż w Polsce nie przepracowała wielu filozoficznych i paradygmatycznych zmian w humanistyce końca XX i początku XXI w.

Przyjęcie, a wręcz tylko zaakceptowanie istnienia orientacji afektywnej w humanistyce nie oznacza, że archiwa państwowe nagle mają działać wyłącznie orientując się na emocje. W archiwistyce w sensie praktycznej działalności status praktykowania tej orientacji zależeć będzie od typu archiwum. Z całą pewnością już teraz na jej stosowanie bardziej otwarte są archiwa społeczne i prywatne, choć i w archiwach publicznych znajdzie się dla niej miejsce. W archiwistyce w sensie nauki o archiwach orientacja ta umożliwia ogromne poszerzenie pola badań.

Warto odnieść się w tym miejscu do szerszego kontekstu nowej humanistyki i spróbować pozycjonować archiwistykę w jej łonie.

Według Ryszarda Nycza nowa humanistyka, w przeciwieństwie do klasycznej, rozwija badania poza standardowym systemem binarnych opozycji pojęciowych, takich jak kultura i natura, poznanie i działanie, historia i pamięć, to, co intelektualne, i to, co afektywne. Zamiast tego te sfery pojęciowe przenikają się $e^{76}$. Stra-

76 R. Nycz, Wstęp. Humanistyka wczoraj i dziś (w wielkim skrócie i nie bez uproszczeń) [w:] Kultura afektu..., s. 11. 
tegia dzisiejszej humanistyki ma z kolei polegać na tzw. praktykowaniu teorii: wyprowadzaniu analitycznych pojęć z empirycznej materii (w przeciwieństwie do weryfikowania z góry założonych teoretycznych kategorii), a także przesunięciu zainteresowania „z wyników, obiektów, wytworów [...] na procesy, praktyki, działania, które nie są rozpatrywane ze względu na efekty, do jakich doprowadziły, lecz z uwagi na swą wewnętrzną logikę, specyfikę własnej sprawczości i kreatywności"77.

W tym samym tekście R. Nycz wprowadza rozumienie humanistycznej innowacyjności, które również może być przydatne w spojrzeniu na archiwistykę zaangażowaną afektywnie. Tak więc humanistyka innowacyjna to: „(a) oryginalne rozwiązanie istotnego problemu (w wymiarze tyleż naukowym, co społeczno-kulturowym), dzięki (b) wypracowaniu powtarzalnej procedury badawczej (niebędącej aplikacją żadnej istniejącej metody), w sposób, który prowadzi do (c) odsłonięcia nowego pola problemowego oraz (d) zainicjowania nowej subdyscypliny czy orientacji badawczej, a równocześnie (e) do stymulowania procesu zmiany w sferach społeczno-kulturowej wiedzy, obyczaju i zachowania, mentalności bądź wrażliwości”78.

Przy czym za nieodłączne autor uznaje kryterium odkrywczości merytorycznej i przydatności społecznej. Ta rama teoretyczna, wraz z postulowaną przez R. Nycza współpracą ze społeczeństwem w ramach humanistyki zaangażowanej, wydaje się być potencjalnie bardzo płodnym podejściem, nie tylko w ramach zastosowania podejścia afektywnego. Tylko czy archiwistyka da radę, a także czy powinna, podążać za afektem i nową humanistyką?

\section{Źródła}

Archiwum Państwowe w Katowicach Oddział w Pszczynie

17/293/0 Powiatowy Inspektorat Szkolny w Pszczynie [1802] 1872-1922, seria 17/293/0/8

Dzieci upośledzone 1888-1915.

Archiwum Państwowe w Szczecinie

65/73/0 Naczelne Prezydium Prowincji Pomorskiej w Szczecinie [1632] 1808-1945, seria 65/73/0/17.5 Szkoły dla dzieci upośledzonych 1823-1934.

77 Ibidem, s. 12.

78 Ibidem, s. 15. 
Narodowe Archiwum Cyfrowe

3/1/0 Koncern Ilustrowany Kurier Codzienny - Archiwum Ilustracji 1910-1939, sygn.

3/1/0/6/2322 Cygan z tresowanym niedźwiedziem na ulicy w Szczawnicy 1919-1930.

3/2/0 Wydawnictwo Prasowe Kraków-Warszawa 1939-1945, sygn. 3/2/0/-/15378 Murzyn i Murzynka chorzy na śpiączkę afrykańską b.d.; sygn. 3/2/0/-/2066 Żołnierze niemieccy podczas rozmowy z Murzynami 1941-1943; sygn. 3/33/0/2/4022 Reportaż o Cyganach - rozmowa z Cyganami na temat ich życia, obyczajów i folkloru 1968.

\section{Bibliografia}

Affect, [w:] Merriam-Webster.com Dictionary, https://www.merriam-webster.com/dictionary/affect [dostęp: 29.07.2021].

Affect and the Archive: Program, https://affectandthearchive.wordpress.com/affect-and-the-archive/program/ [dostęp: 30.07.2021].

Altieri C., The Particulars of Rapture: An Aesthetics of the Affects, Nowy Jork-Londyn 2004.

ARA Emotional Support Guidelines, 2017, https://www.archives.org.uk/what-we-do/emotional-support-guides.html [dostęp: 1.08.2021].

Archivo Artea. Archivos de afectos, http://archivoartea.uclm.es/contextos/archivos-de-afectos/ [dostęp: 31.07.2021].

Brilmyer G., Archival assemblages: applying disability studies' political/relational model to archival description, „Archival Science” 2018, t. 18, z. 2, s. 95-118, DOI: 10.1007/s10502-018-9287-6 [dostęp: 23.07.2021].

Brown E.H., Archival Activism, Symbolic Annihilation, and the LGBTQ2+ Community Archive, „Archivaria” 2020, t. 89, s. 6-33, https://archivaria.ca/index.php/archivaria/article/ view/13729 [dostęp: 23.07.2021].

Burzyńska A., Afekt - podejrzany i pożądany, [w:] Kultura afektu - afekty w kulturze. Humanistyka po zwrocie afektywnym, red. R. Nycz, A. Łebkowska, A. Dauksza, Warszawa 2015, s. 115-134.

Caswell M., Dusting for Fingerprints: Introducing Feminist Standpoint Appraisal, „Journal of Critical Library and Information Studies" 2020, t. 3, z. 1, https://journals.litwinbooks.com/index.php/ jclis/article/view/113/67 [dostęp: 23.07.2021].

Caswell M., Feeling Liberatory Memory Work: On the Archival Uses of Joy and Anger, „Archivaria” 2020, t. 90, s. 153, https://archivaria.ca/index.php/archivaria/article/view/13763 [dostęp: 23.07.2021].

Chorążyczewski W., Archiwistyka dla poczq̨tkujących, Toruń 2014, https://repozytorium.umk.pl/ handle/item/2191 [dostęp: 1.08.2021]. 
Chorążyczewski W., Roszak S., Pamięć rodu Komierowskich, Torun 2002.

Cifor M., Affecting relations: introducing affect theory to archival discourse, „Archival Science“ 2016, t. 16, z. 1, s. 7-31.

Cifor M., Aligning Bodies: Collecting, Arranging, and Describing Hatred for a Critical Queer Archives, „Library Trends” 2016, t. 64, z. 4, s. 756-775, https://www.ideals.illinois.edu/bitstream/handle/2142/94939/64.4.cifor.pdf [dostęp: 23.07.2021].

Cifor M., Presence, Absence, and Victoria's Hair: Examining Affect and Embodiment in Trans Archives, „Trangender Studies Quarterly” 2015, t. 2, z. 4, s. 645-649, DOI: 10.1215/23289252-3151565 [dostęp: 23.07.2021].

Cook T., Schwartz J.M., Archives, records, and power: From (postmodern) theory to (archival) performance, „Archival Science” 2002, t. 2, z. 3-4, s. 171-185, DOI: 10.1007/BF02435620 [dostęp: 23.07.2021].

Cooper D., House proud: an ethnography of the BC Gay and Lesbian Archives, „Archival Science” 2016, t. 16, z. 3, s. 261-288, DOI: 10.1007/s10502-015-9250-8 [dostęp: 23.07.2021].

Cvetkovich A., An Archive of Feelings, Durham 2003.

Degen R., Garść uwag na temat selekcji w Polsce, [w:] Archiwistyka na uniwersytetach, archiwistyka w archiwach, Toruńskie Konfrontacje Archiwalne, t. 1, red. W. Chorążyczewski, A. Rosa, Toruń 2009, s. 133-143.

Degen R., Urzędnicy, selekcja i brakowanie dokumentacji w Polsce w XX wieku, [w:] Dzieje biurokracji na ziemiach polskich, red. A. Górak, K. Latawiec, D. Magier, t. 3, Lublin-Siedlce 2010, s. 545-555.

Douglas J., Alisauskas A., It Feels Like a Life's Work - Recordkeeping as an Act of Love, „Archivaria” 2021, t. 91, s. 6-37.

Duranti L., The Concept of Appraisal and Archival Theory, „The American Archivist” 1994, t. 57, z. 2, s. 328-244.

Flinn A., Archival activism: independent and community-led archives, radical public history and the heritage professions, „InterActions” 2011, t. 7, z. 2, DOI: 10.5070/D472000699 [dostęp: 23.07.2021].

Górak A., Magier D., Selekcja archiwalna jako konstruowanie zasobu źródeł historycznych, „Archiwa Kancelarie - Zbiory" 2011, nr 2 (4), s. 131-143.

Guldi J., What is the Spatial Turn?, n.d., https://spatial.scholarslab.org/spatial-turn/what-is-the-spatial-turn/ [dostęp: 23.07.2021].

Harris V., The archival sliver: power, memory and archives in South Africa, „Archival Science” 2002, t. 2, z. 1-2, s. 63-86.

Hobbs C., The Character of Personal Archives: Reflections on the Value of Records of Individuals, „Archivaria” 2001, t. 52, s. 126-135. 
Horodecka M., Afekty i emocje w reportażu literackim. Perspektywa genologiczna i antropologiczna, [w:] Kultura afektu - afekty w kulturze. Humanistyka po zwrocie afektywnym, red. R. Nycz, A. Łebkowska, A. Dauksza, Warszawa 2015, s. 415-441.

Huang T., Nie R., Zhao Y., Archival knowledge in the field of personal archiving: an exploratory study based on grounded theory, „Journal of Documentation” 2021, t. 77, z. 1, s. 19-40, DOI: 10.1108/ JD-04-2020-0071 [dostęp: 23.07.2021].

Jóźwik A., Martini N., Realia funkcjonowania archiwów społecznych i czynniki sprzyjajace ich rozwojowi, [w:] Archiwistyka społeczna. Diagnoza i wyzwania, praca zbiorowa, Warszawa 2017, s. 62-75, https://cas.org.pl/wp-content/uploads/2021/03/archiwistyka-spoleczna-diagnoza-i-wyzwania.pdf [dostęp: 23.07.2021].

Kosofsky Sedgwick E., Frank A., Shame in the Cybernetic Fold: Reading Silvan Tomkins, „Critical Inquiry" 1995, t. 21, z. 2, s. 496-522.

Kwiatkowska W., Co mogq, a co powinny wiedzieć o naszych czasach przyszłe pokolenia. Kulturowe aspekty selekcji dokumentacji, „Archeion” 2011, t. 112, s. 191-204.

Laurent N., Hart M., Building a trauma-informed community of practice, „Education for Information” 2020, t. 37, z. 1, s. 1-6, DOI: 10.3233/efi-190363 [dostęp: 1.08.2021].

Laurent N., Hart M., Emotional Labor and Archival Practice - Reflection, „Journal of the Society of North Carolina Archivists" 2018, t. 15, s. 13-22, http://www.ncarchivists.org/wp-content/ uploads/2019/02/jsnca_vol15_laurent-hart-1.pdf [dostęp: 1.08.2021].

Laurent N., Wright K., A trauma-informed approach to managing archives: a new online course, „Archives and Manuscripts” 2020, t. 48, z. 1, s. 80-87, DOI: 10.1080/01576895.2019.1705170 [dostęp: 1.08.2021].

Lee J.A., Be/longing in the archival body: eros and the "Endearing” value of material lives, „Archival Science" 2016, t. 16, z. 1, s. 33-51, DOI: 10.1007/s10502-016-9264-x [dostęp: 23.07.2021].

Markowski M.P., Emocje. Hasło encyklopedyczne w trzech częściach i dwudziestu trzech rozdziałach (nie licząc motta), [w:] Pamięć i afekty, red. Z. Budrewicz, R. Sendyka, R. Nycz, Warszawa 2014, s. 345-366.

Marshall D., The Queer Archive: Teaching and Learning Sexualities in Australia, „Transformations: The Journal of Inclusive Scholarship and Pedagogy" 2010/2011, t. 21, z. 2, s. 36-46.

Massumi B., The Autonomy of Affect, "Cultural Critique” 1995, t. 31, z. 2, s. 83-109, DOI: 10.2307/1354446 [dostęp: 23.07.2021].

Material Powers: Cultural Studies, History and the Material Turn, red. T. Bennett, P. Joyce, Nowy Jork 2010.

Nash K., The 'Cultural Turn' in Social Theory: Towards a Theory of Cultural Politics, „Sociology” 2001, t. 35 , z. 1, s. $77-92$. 
Nycz R., Wstęp. Humanistyka wczoraj i dziś (w wielkim skrócie i nie bez uproszczeń), [w:] Kultura afektu - afekty w kulturze. Humanistyka po zwrocie afektywnym, red. R. Nycz, A. Łebkowska, A. Dauksza, Warszawa 2015, s. 7-24.

Radick C., Romance Writers' Use of Archives, „Archivaria” 2016, t. 81, s. 45-73, https://archivaria.ca/ index.php/archivaria/article/view/13558 [dostęp: 23.07.2021].

Robótka H., Zasady i metody selekcji dokumentacji tradycyjnej i elektronicznej a potrzeby badań obecnych i przysztych, https://docplayer.pl/11414229-Zasady-i-metody-selekcji-dokumentacji-tradycyjnej-i-elektronicznej-a-potrzeby-badan-obecnych-i-przyszlych.html [dostęp: 31.07.2021].

Rosa A., Funkcja edukacyjna archiwów, Warszawa 2012.

Schoenebeck S., Conway P., Data and Power: Archival Appraisal Theory as a Framework for Data Preservation, „Proceedings of the ACM on Human-Computer Interaction” 2020, t. 4, z. CSCW2, art. nr 162, s. 1-18, DOI: 10.1145/3415233 [dostęp: 23.07.2021].

Schwartz J.M., Cook T., Archives, records, and power: The making of modern memory, „Archival Science” 2002, t. 2, z. 1-2, s. 1-19, DOI: 10.1007/BF02435628 [dostęp: 23.07.2021].

Sloan K., Vanderfluit J., Douglas J., Not 'Just My Problem to Handle': Emerging Themes on Secondary Trauma and Archivists, „Journal of Contemporary Archival Studies” 2019, t. 6, https://elischolar.library.yale.edu/jcas/vol6/iss1/20/ [dostęp: 1.08.2021].

Surkis J., When Was the Linguistic Turn? A Genealogy, „The American Historical Review” 2012, t. 117, z. 3, s. 700-722, DOI: 10.1086/ahr.117.3.700 [dostęp: 23.07.2021].

Taves Sheffield R., Documenting Rebellions: A Study of Four Lesbian and Gay Archives in Queer Times, Sacramento 2020.

Tincineto Clough P., Introduction, [w:] The Affective Turn: Theorizing the Social, red. P. Ticineto Clough, J. Halley, Durham 2007, s. 1-33.

Wakimoto D., Bruce C., Partridge H., Archivist as Activist: Lessons from Three Queer Community Archives in California, „Archival Science” 2013, t. 13, z. 4, s. 293-316, DOI: 10.1007/s10502013-9201-1 [dostęp: 23.07.2021].

Wiśniewska-Drewniak M., Inaczej to zniknie. Archiwa społeczne w Polsce - wielokrotne studium przypadku, Toruń 2019.

X A., Campbell T., Stevens M., Love and Lubrication in the Archives, or rukus!: A Black Queer Archive for the United Kingdom, „Archivaria” 2010, t. 68, s. 271-94, https://archivaria.ca/index.php/ archivaria/article/view/13240 [dostęp: 23.07.2021].

Żylińska J., Czy mamy bać się końca świata? Afekt, geologia i posthumanizm jako wyznaczniki nowego horyzontu w humanistyce, tłum. P. Poniatowska, [w:] Kultura afektu - afekty w kulturze. Humanistyka po zwrocie afektywnym, red. R. Nycz, A. Łebkowska, A. Dauksza, Warszawa 2015, s. 49-69. 